\title{
Możliwości rozwoju terenów rekreacyjnych na obszarze Ruczaju w Krakowie
}

\section{Potential for the development of recreational areas in the district of ruczaj in Kraków}

\section{Streszczenie}

Artykuł skupia się na wyzwaniach dynamicznego rozwoju dzielnicy Ruczaj jako dzielnicy mieszkaniowej Krakowa na przeło-

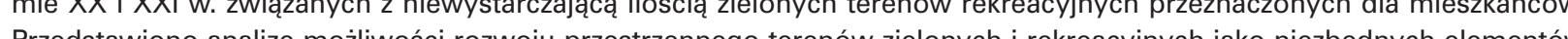

\section{Abstract}

This article focuses on the challenges associated with the dynamic development of the district of Ruczaj as a housing neighbourhood of Krakow during the turn of the twenty-first century. These challenges are associated with the insufficient amount of recreational areas that can be used by residents. An analysis of the spatial development potential of green and recreationa reas, seen as necessary elements of a sustainable housing environment, has been presented in the article.

Stowa kluczowe: tereny rekreacyjne, Ruczaj, tereny rekreacyja,
Keywords: recreational areas, Ruczaj, housing environment

\section{Wrowadzenie}

Znaczenie terenów zielonych $w$ ksztaltowaniu wspótczesnego miasta dostrzeżono już w latach 30. ubieglego wieku, kiedy to w Karcie Atenskiej' pojawity się postulaty rozieszani zelony. Dostep i zachomanie tereńw przyroc niczych jest również jednym z najważniejszych postulatów zrównoważonego rozwoju. Urbanizacja współczesnych miast sprawia, że wiele terenów przyrodniczych $w$ ich obrębie jest zabudowywanych, a nowe inwestycje, zwłaszcza mieszkaniowe często nie do konca zapewniają ich mieszkańcom kontakt $z$ zielenia $i$ dostęp do terewow reke polityki zwiazane z rozwojem i zarzagdzaniem te renami zielonymi, a wartość przyrody w obszarach miejskich dostrzeżona została przez Komisje Europejska, która w 2008 r. zainicjowała program "Zielona Stolica Europy” przyznawany miastom, które wyróżniają się w zakresie poprawy jakosci zycia mieszkanców $i$ ochrony przyrody. Władze Krakowa również rozpoczęly realizację szersze polityki związanej z terenami zieleni, ${ }^{2}$ co jest szczególnie
ważne, ponieważ jest to miasto, które w skali Polski znajważne, ponieważ jest to miasto, które w skali Polski znajzielonych $w$ granicach administracyinych.

\section{Introduction}

of green areas in the shaping of the con acknowledged already in the 1930s, when the Athens Charter' revealed its postulates tor the development of green recreational areas in housing zones. Access and the preservation of natural areas is also one of the most important postulates of sustainities cities leads to many green areas within their administrajects, pariong not pride eno those that involve housing, often do access to recreational area to their residents. At present an increasing number of cities is conducting its owreen The value of nature in urban areas having been acknowhedged by the European Commission, which initited the European Green Capital Award programme in 2008 , with the award being given to cities that excel in improving the quality of life of their residents and environmenta protection. The authorities of Krakow have also bega mplementing a broader policy associated with green
Rozwój struktury mieszkaniowej i funkcjonalnej Ruczaju w XX wiek

Ruczaj jest jedną z dzielnic Krakowa, która od początk XXI wieku znalazła sie wśród najbardziej dynamicznie rozwijających sie czę́si stolicy Małopolski. Należy tu wsposa naibardziej charakterystyczna zabudowa Ruczaju, ale również o terenach Kampusu Uniwersytetu Jagiellońskiego oraz siedzibach licznych firm, zwlaszcza z sektora

Historycznie obecny szeroko rozumiany obszar Ruczaut obejmuje dawne tereny wsi rozposcierajacych sie strony południowej. Przez długi czas teren ten znany by głównie dzieki temu ostatniemu, gdyz we wsi Kobierzy w 1917 r. oddano do użytku Krajowy Zakład dla Umysłowo Chorych - szpital psychiatryczny, który był zaliczan do największych i najnowocześniejszych w owczesne Europie. Polnocna częśc Ruczaju na opracowaniach kawa z 1912 r.6 i obejmuje obecne tereny w okolicach ulic Na mapie Planu Wielkiego Krakowa z $1944 \mathrm{r}$. widać juz włączone do miasta w czasie drugiej wojny światowe tereny obecnego Ruczaju, które ciagna sie aż do wspomnianego juz kompleksu szpitala w Kobierzynie? kim tereny rolnicze oraz rozdrobniona zabudowe wiejską koncentrującą się wzdłuż obecnej ul. Kobierzyńskiej. Pierwsze większe zespoły mieszkaniowe zaczęły tu powstawać dopiero w połowie lat 80. XX wieku na zachód od rzeki Wilgi pomiędzy dzisiejszymi ulicami Grota-Roweckiego, Lipinskiego, Milkowskiego i Kobierzyńską az mieszkaniowa, która tam powstała to oudynki budow ne $w$ technologii wielkiej płyty o wysokości od 4 do 10 kondygnaciji. Osiedle charakteryzuje sie dobrze zarysowaną kompozycją urbanistyczną, dużą ilością otwartych terenów zielonych pomiędzy budynkami oraz pewna ilościa usług ${ }^{8}$. Od konca lat 90. ubieglego wieku na Ru czaju zaczęly sie pojawiac budynki mieszkaniowe budobudowlanymi $w$ cześciowo postmodernistycznym stylu charakterystycznym dla końca lat 90 . XX wieku. Nowe inwestycje budowlane powstawały jako pojedyncze budynki lub grupy kilku bloków mieszkaniowych. Nie byty jednak połączone kompozycyjnie w jedną całość tak jak osiedla $z$ la 80 . Posteppuaca fragmentaryzacja przestrze niezależni od siebie prywatni inwestorzy budowali z re guły na pojedynczych, wydzielonych dziatkach, w pewnym stopniu powtarzając ich układ nawiązujący do historycznego tanowego układu pól. Równocześnie wraz z zabudowa mieszkaniową po drugiej stronie ul. Bora Komorowskiego zaczely powstawac pierwsze inwestycje nóskiego oraz Bibliotek Uniwersytetu PapieskiegagiJana Pawła II.

W 2012 r. oddana została do użytku linia tramwajowa biegnąca od ul. Kapelanka w kierunku południowym do przystanku Czerwone Maki, gdzie zlokalizowano rownież parking ParkধRide. Dzięki tej inwestycji zmieniła się jakoś usług transportowych $\mathrm{W}$ catej dzielnicy, która wcześnie Rozbudowa linii tramwajowej na Ruczaj znacznie podniosła atrakcyjność tej dzielnicy jako dobrze skomunikowanej z centrum Krakowa. Obecnie dzięki linii tramwajowe rozbudowywane się tereny na południe od przystanku areas ${ }^{2}$, which is particularly important as it is a city that its administrative borders in Poland.

The development of Ruczaj's housing and functional tructure in the twentieth century

thezaj belongs to a group of Krakow's districts that parts of Lesser Poland's capital during the early years of the twenty-first century. Of note here are not only housing projects, which are the most distinct type of Ruczaj's development, but also the grounds of the Jagiellonian University Campus and the buildings of many companies, particularly from the IT and BPO sector.4

Historically, what is generally considered to be the territoy of Ruczaj covered the former territories of villages that stretched between Kapelanka Street in the north and Kobierzyn in the south. The area was associated with the latter for a long time, as the village of Kobierzyn was the site of the National Institution for the Mentally III, which opened The to be among the largest and most advanced institution concerned, the northern pert of Ruczaj con be seen on the Plan of Greater Krakow from $1912^{6}$, covering what are now the areas around Grota-Roweckiego, Rostworowskiego and Ruczaj streets. On the map of the Plan of Greater krakow from 1944 we can see the areas of what is now Ruczaj being incorporated into Krakow, stretching as far as the previously mentioned psychiatric hospital complex in Kobiazn. The structure of this part of Krakow included prmarily farmland and granular rural development tha was grouped around what is now Kobierzyñska Street. The midle What af ne 1980, to the west of the Wiga river, between ego and Kobierzyńska street and Zachoogni, Mirkowskresidential builings that were erected at the time were composed of 4-10 storey panel housing blocks. The housing estate is characterised by a well-defined urban composition, a chrge amount of open green areas between buildings and the presence of some services ${ }^{8}$. Since the end of the 1990s, the area of Ruczaj has begun to see the construction of masonry housing with new constructio solutions, often maintained in a postmodernist architecturarle disthet of the end of the 1990s. New development prejects took on the form of individual buildings or complexes of a couple of housing blocks. They were not linked f the 198 , compositional whole as the housing estates

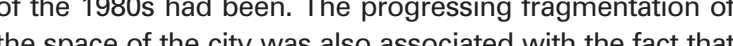
various privat de als typically bult on individul fenced-off plots, repeating their layout, which was similar to the historical fan-like land division. Simultaneously, the other side of Grota-Roweckiego Street began seeing the first projects involving the construction of university buildings-the Jagiellonian University Campus and the John Paul II University Library.

In 2012, a tram line that runs from Kapelanka Street towards the south, to the Czerwone Maki tram stop, was opened for use. The area of the stop is also the site of ted to a shift in the quality of transport services in the 
wanego w 2016 r. na zlecenie władz miasta ${ }^{13}$. Dzielnica cały czas intensywnie się rozwija i ilość jej mieszkańców wzrasta, co wzmaga również zaspokojenia ich potrzeb
w zakresie dostepu do terenów zielonych oraz możliwoW zakresie dostepu do terenow zielonych oraz możliwo scl spędzania czasu wo tiego. Rów Kocześnie z zabudowa cownicy $i$ studenci korzystaja $z$ usług $i$ staja sie również użytkownikami terenów rekreacyjnych na Ruczaju. Tereny miejskie są szczególnie dotkliwie narażone na negatywne skutki zmian klimatycznych, które nasilaja się
w ostatnim czasie. Według "Global Risk Report $2018^{\prime \prime}$ największym globalnym zagrożeniem dla gospodarek panstwowych beeda nasilające się zagrożenia środowiskowe, katastrofy naturalne oraz ekstremalne zjawiska
pogodowe.14 To przede wszystkim susze, upały, nagte i intensywne opady, a także zanieczyszczenie powietrza. Zjawiska te powodują nie tylko skutki ekonomiczne, lec wpływają również na zdrowie i życie ludzi, co jest bardzo widoczne $w$ dużych skupiskach ludzkich - w miastach, a w szczególności w ich obszarach mieszkaniowych. Pojawiaja się również bardzo niekorzystne skutki zdrowotW miastach zwtaszcza silnie nab zdrowie wptywaia długookresowe upały, ponieważ duża ilość powierzchni zabudowanych pochłania więcej promieni słonecznych niz odbija, a intensywny ruch samochodowy, mała ilość terenów zielonych i wody i brak przewietrzania potęguja to zjawisko. Zanieczyszczenie powietrza może doprowadzic do różnego rodzaju chorób płuc, astmy, alergii, zwiększa szczególnie dotykaja osoby starsze i mate dzieci, moga powodować udary cieplne, odwodnienie organizmu, zaostrzać choroby sercowo-naczyniowe, a nawet zwiekszac ryzyko udarów. Suche powietrze bez wiatru $w$ mieście wzmaga doznania wysokiej temperatury i obniża wydajnosc organizmu i samsopoczucie psychofizyczne

Przeciwdziałanie zmianom klimatycznym wymaga globalpomoca odpowiedniego mozpodarowania prowac za pomocą odpowiedniego gospodarowania przestrzenia
miejską zapewniając duży udziat powierzchni biologicznie czynnych w obszarach miejskich. Wspótczesne tereny zielone stają się więc narzędziem umożliwiającym lokalne zmiany negatywnych zjawisk klimatycznych, co jest szczegölnie wazne w obszarach mieszkaniowych, w których te zjawiska wpływają na zdrowie całych społeczności ite. cza dużych dzielnic takich jak obszar Ruczaju w Krakowie,

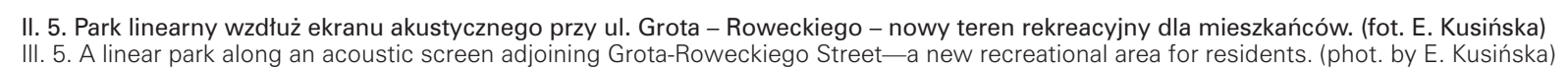

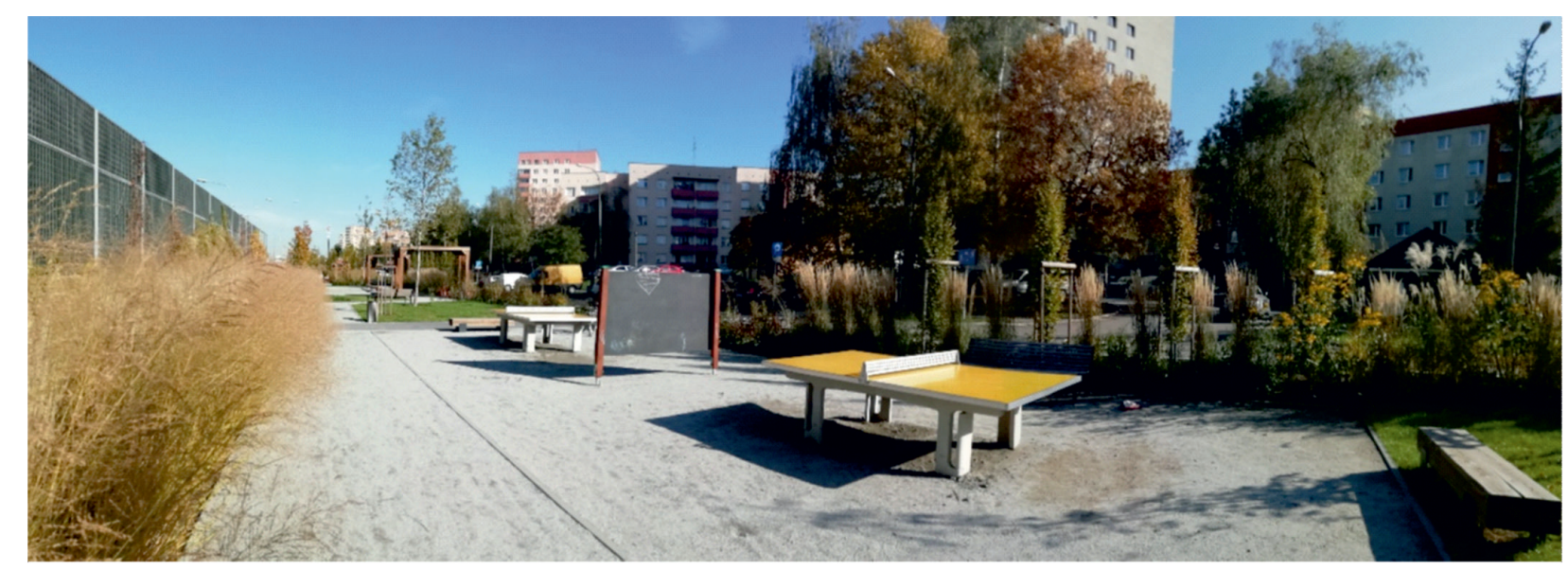

winno zatem odbywac się z uwzględnieniem tzw. „zielonej infrastruktury", która powinna stać się równie ważn jak infrastruktura komunikacy na czy techniczna. ${ }^{17}$ spoołcześnie obszary mieszkaniowe określa się pojęciem srodowiska mieszkaniowego czyli przestrzeni nie ogran dowiska je otaczajacego, które zapewnia mieszkańcom osiedli odpowiedni komfort życia, bezpieczeństwo, poczucie wspólnoty i przynależności. Wpływ na jakość srodowiska mieszkaniowego ma więc nie tylko architektura samych budynków, ale równieź kompozycja przestrzenn czymi ${ }^{18}$ Odpowiednia struktura rekreacyinych terenć zielonych w obszarach catych dzielnic takich jak Rucza powinna zapewnić jego mieszkańcom odpowiedni kom ort zamieszkania i uksztattować wartościowe środowisko mieszkaniowe.

Możliwości rozwoju terenów rekreacyjnych na Ruczaju Pomimo wielu negatywnych zjawisk, które pojawiły się wraz z intensywnna rozbudowa dzielnicy, ma ona nadal potencjał do zbudowania zielonej infrastruktury. W okolicy dzielnicy Ruczaj pojawiaja sie miejskie inwestycje $w$ tereny zielone, na północy budowany jest obecnie park w dawnym kamieniołomie na Zakrzowku, a na południu udostepniany jest Las Borkowski. ${ }^{19} \mathrm{Sa}$ to
duże obszary przyrodnicze o charakterze rekreacyjnym bardzo dobrze skomunikowane $z$ dzielnica. $W$ samym jej centrum zlokalizowany jest obszerny teren zielony, który wraz z Krakowskim Klubem Jazdy Konnej stanowi obszar objetty miejscowym planem zagospodarowania terenu Park Ruczaj-Lubostroń. Jest to bardzo cenny
przyrodniczo teren o zachowanej dużej ilości starych przyrodniczo teren o zachowanej dużej ilości starych
drzew oraz ze znajdującymi się tam zbiornikami wodnymi, drzew oraz ze znajdującymi się tam zbiornikami wodnymi, chętnie odwiedzany przez okolicznych mieszkańców i bardzo dobrze

Kobierzyńskiej.

Plan dla Parku Ruczaj-Lubostroń przewiduje przede wszyst kim zachowanie terenów zielonych, w szczególnośc ochronę licznych bytujacych tam obecnie gatunków flor Teren ten powinien przeksztatcić sie w park dzielnicowy miejsce służace mieszkańcom całej jednostki administracyjnej. Jest to typ terenu rekreacyjnego o wielofunkcyjnym programie, jako dogodne miejsce rekreacji różnych grup społecznych i wiekowych, a sąsiedztwo Krakowskiego Klu bu Jazdy Konnej umożliwia wprowadzenie do program ważne jest też zachowanieje ${ }^{20}$ dawnych stawów duja sie w okolicy ul Szuwarowej. Obecnie bardzo zanie dbane, mają szansę stac się najbardziej atrakcyjną przestrzenią przyciągającą mieszkańców.

Główne korzyści, jakie płyną z tworzenia parków dzielnico wych to zapewnianie miejsc rekreacji dla społeczności lokalnych'21. Parki dzielnicowe spełniaja jednak jednocześnie ści, nadają poszczególnym obszarom miasta indywidualny charakter. Duże tereny parków dzielnicowych umożliwiaja ochronę przed nadmierną zabudową i jej negatywnym konsekwencjami, polepszaja jakość środowiska przyrodn czego, stają się również istotnymi miejscami spotkań i integracji mieszkańców $w^{23}$, które można rozpatrywać w kategori czaj, w obliczu chaotycznej, bezplanowej zabudowy i nacisku deweloperskiego parki miejskie i miejskie enklawy zieleni moga stać się swoistymi zwornikami i wyróżnikam
przestrzeni miejskiej. intense sensation of high temperature, lowering physical performance and psycho-physical well-being.

Countering climate change requires global efforts, but its effects can also be alleviated using the proper management of urban space, ensuring a high share of biolog cally active suffaces in urban areas. Contemporary green areas thus become a tool that enables local change in distere climate phenomena, which is particularly imporalth of entire comm whit such phenomena affect of housing areas, particularly large districts like Ruczaj i Krakow, should take "green infrastructure" into consider ation. This infrastructure should become equally important to circulation or technical infrastructure.

At present, housing areas are described as a housing environment, which is a space that is not limited solely to the apartment or the building, but one that is also comprised of the surrounding environment, which ensures the residents of housing areas can enjoy a proper comfort of living, safety and a feeling of community and belonging. The housing environment is therefore affected not only by the architecture of its constituent buildings but also the spatial composition of the entire surrounding area and contact with natural elements's. A proper of an entire district such as Ruczaj should provide its residents with an appropriate housing comfort and ensure a full-featured housing environment.

The potential for the development of recreational areas in Ruczaj

Despite many negative phenomena that have appeared along with the dense development of the district, it has retained its potential for the establishment of a green infrastructure. The vicinity of the district of Ruczaj features public park projects, with a park currently being built in the former quarry of Zakrzowek, while to the south the residents can access the Borek Forest. ${ }^{19}$ These are large natural areas with a recreational character and are well linked with the distric. In its centre there is an extensive green area, which, along with the Krakow Horse Riding Club, constitutes an area cov It is an area that is very valuable because of its wildlife, with many old trees and lakes, and is currently undeveloped does attract local residents and is easily accessible, primarily from the side of Kobierzyńska Street

The Park Ruczaj-Lubostroń land development plan largely features the preservation of green areas, especially involving the protection of many species of flora and fauna that inhabit them, including the habitats of many species of waterfowl. This area should be converted into a distric park-a place that can serve the residents of the entire administrative unit. It is a type of recreational area with amulti-functional programme, constituting a comfortable place for the recreation of many social and age groups, While the vicinity of the Krakow Horse Riding Club makes in possible to include active recreation into the park's programme. It is very important to preserve the area's old Street. They are in a state of considerable neglect, bu have the potential to become a highly attractive space. The main benefit of the establishment of district parks is providing a place of recreation for local communities ${ }^{2}$. 


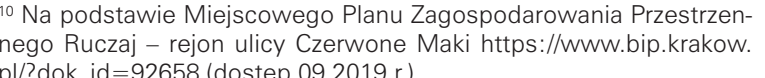

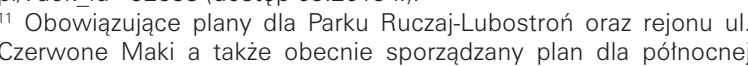

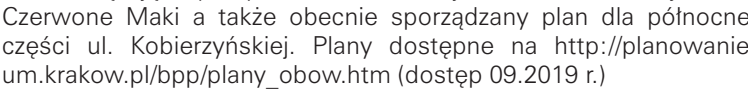

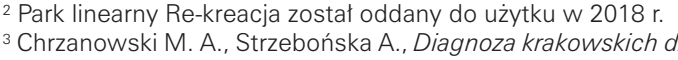

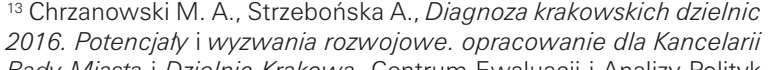
Ewaluacji i Analizy Polityk

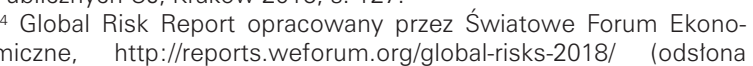
miczere,
$0.2019 \mathrm{r}$.

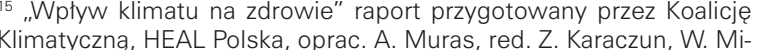
chalak, Polski Klub Ekologicany Wargsana 2018 ,

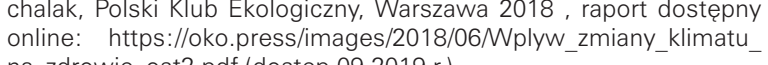

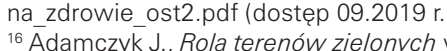
skutkow procesu urbanizacyinego, W: Premiany strutury pree-

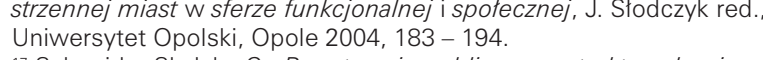

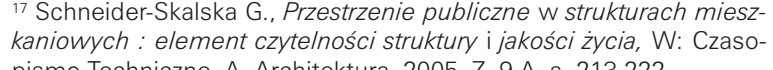

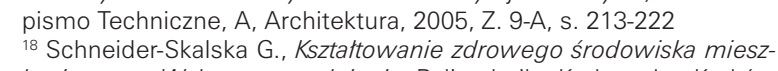

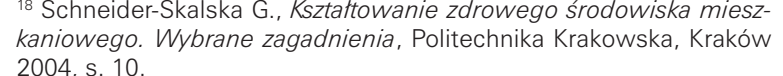

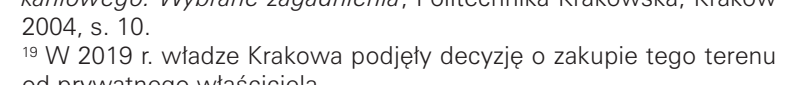
${ }_{20} \mathrm{~W}$ planie zagossodarowania terenu iest to odrebnie wydzielony

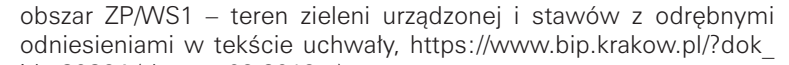

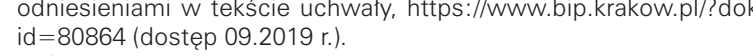

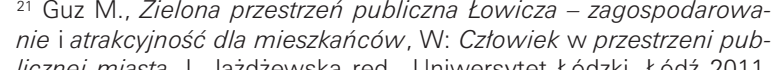

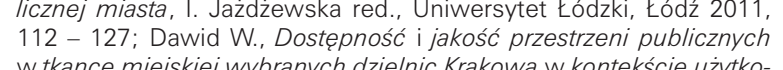

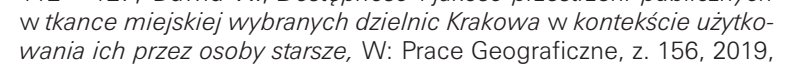

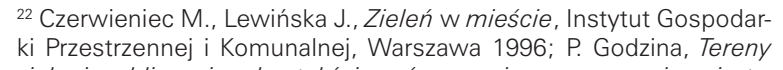

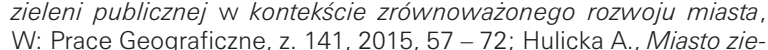

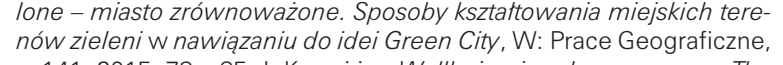

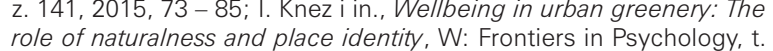

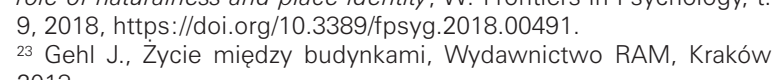

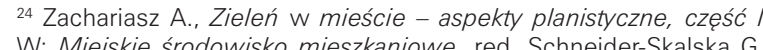

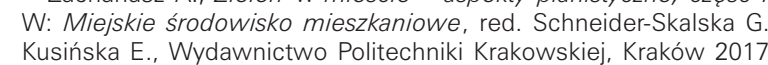

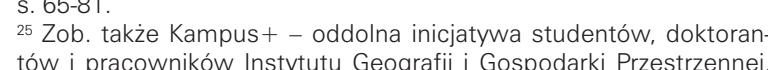

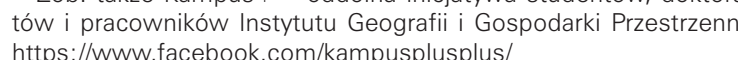
LITERATURA

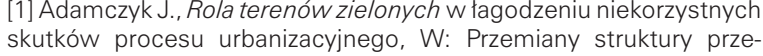
strzennej miast w sterze tunkcionalneij s spotecznei, J. Stoddzzk red. [2] Chrzanowski M. A. Strzebońska A., Diagnozza krakowskich dziet-

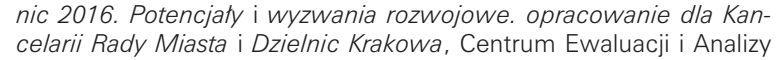

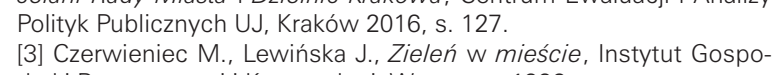

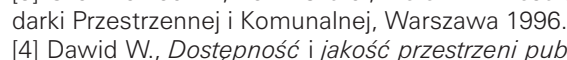

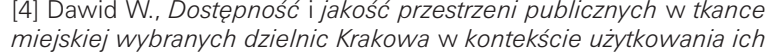

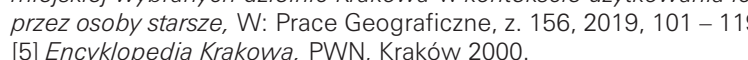

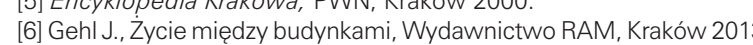

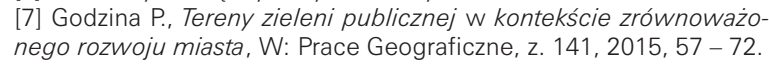

stulates concerning modem urban planning. Cl. Karta atenska/Le Corbu

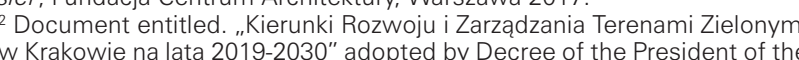
W Krakowie na lata 2019-2030" adopted by Decree of the President of the
City of Krakow no. 2282/2019 of the ninth of September 2019 . 3 Ranking of district cities prepared by BIOAdata, based on data provided

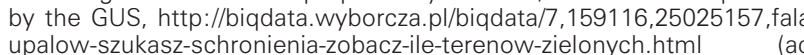

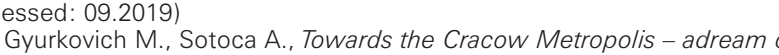
a reality? A selected issues, W: Technical Transactions/CZasopismo Tect-
niczne, 2018. Vol 115. Iss. 2. 5- 25 5 Encyklopedia Krakowa, PWN, Kraków 2000 and http://www.dzielnica

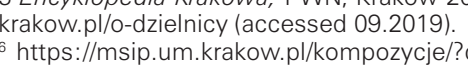

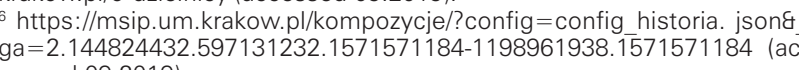
cessed 09.2019$)$
7 Mydel R., RozW

R.a., Rozw Wój struktury przestrzennej miasta Krakowa, PAN, OssolKolisz K., Ktosak A. K., Bucka A. Ziarko B., Moiliwości rewitalizacii ukta

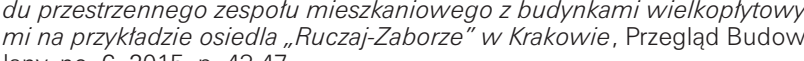

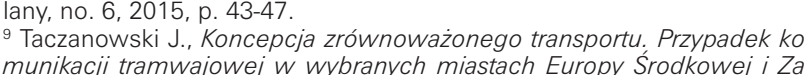
chodniej, Prace Geograficzne, b. 144, 2016, p. $105-125$.

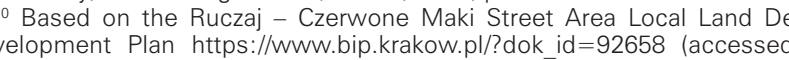
09.2019 Applicable plans for the Ruczaj-Lubostroń Park and the area of Czersection of Kobierzyńska Street. Plans avaialble at: http://planowanie. 12 The Re-kreacjal linear park was delivered in 2018 . 3 Chrzanowski M. A., Strzebońska A., Diagnoza krakowskich dzielnic

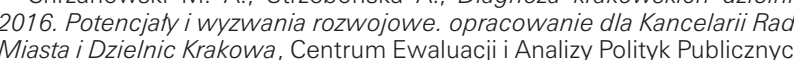

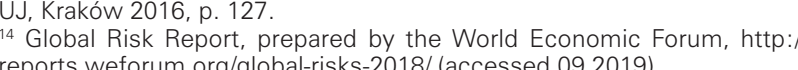
".Wptyw klimatu na zdrowie" report by Koalicja Klimatyczna, HEAL Polska, by: A. Muras, ed. Z. Karaczun, W. Michalak, Polski Klub EkologiczWplyw_zmiany Klimatu_na_drowie ost2. podf laccessed: 09.2019). Adamczyk J., Rola terenow zielornych w lagodzeniu niekorzystrnych sku kow procesu urbanizacyinego, In: Przemiany struktury przestrzennej miast Opole 2004, 183-194.
17 Schneider-Skalska G., Przestrzenie publiczne w strukturach mieszkanjowych : element czytelności struktury i jakości życia, W: Czasopismo

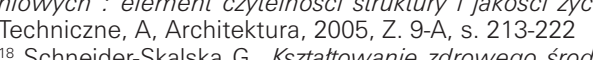

Schnelider-Skalska G., Kstattowanie zdrowego środowiska mieszkanio 9
9 ${ }_{20}^{20}$ Thiva landdevelopment plan features a separate land class marked ZP WS1-landscaped greenery and ponds, with separate provisions in the
text of the resolution, https://www.bip..rakow.pl/?dok_id $=80864$ (accessed: 09.2019). ${ }^{21}$ Guz M., Zielona przestrzeń publiczna Eowicza - zagospodarowanie
${ }^{2}$ trakcyjóść dla mieszkańców. In: Cztowiek w wrzestreni publicznei mia

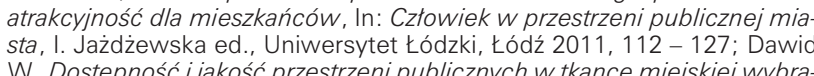
W., Dostepnosci jakość przestrzeni publicznych w wkance miejskiej wybra nych dzieilnic Krakowa w kontekście uìtkowania ich przez osoby starsze.
In: Prace Geograficzne, b. 156, 2019, 101 - 119 . 22 Czerwieniec M., J. Lewíńska, Zieleń w mieście, Instytut Gospodarki Prze-
strzenneji Komunalnej, Warszawa 1996; P. Godzina, Tereny zieleni publiczne W kontekście zrównowazionego rozwoju miasta, In: Prace Geograficzne,
141, 2015, 57 - 72; A. Hulicka, Miasto zielone - miasto zrównoważone. Spo

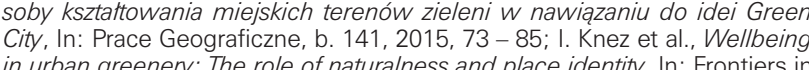
in urban greenerv: The role of natural hess and place identity, In: Frontiers

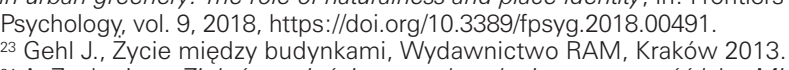

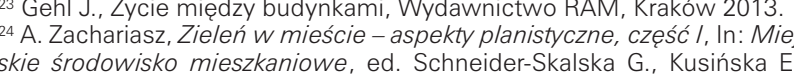

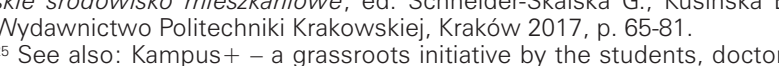
25 See also: Kampust - a grassroots initiative by the students, doctora
candidatas and employees of the Institute of Geography and Spatial ManBIBLIOGRAPHY

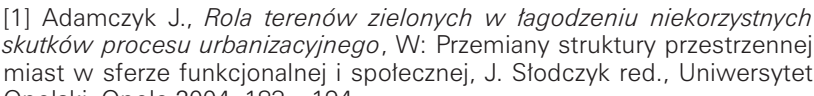

[8] Guz M. Zielona przestrzen publiczna Lowicza - zagospodarowanie
iatrakcyinośc dla mieszzańcón. W. Cztowiek w przestrzeni publicznej

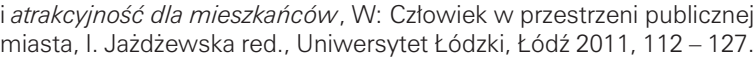
[9] Gyurkovich M., Sotoca A., Towards the Cracow Metropolis - a
dream or a realiti? A selected issues, W: Technical Transactions/Czasopismo Techniczne, 2018, Vol. 115, Iss. 2, s. 5-25

[10] Hulicka A., Misto zielone - miasto zrównowazione. Sposoby City, W: Prace Geograficzne, z. 141, 2015, 73- 85 .

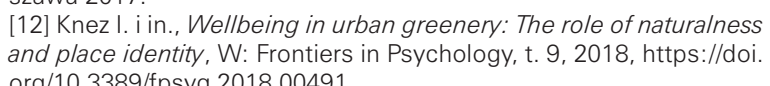
III) Kolisz K. K. Kosak A. K., Bucka A., Ziarko B., Możliwości rewita-
lizaciji uktadu przestrzennego zespotu mieszkaniowego z budynkami lizaciji uktadu przestrzennego zespotu mieszkaniowego z budynkami
wielkoptytowymi na pryyktadzie osiedla "Ruczaj-Zaborze" w KrakoWie, W: Przeglad Budowlany nr 6, 2015, "s. $43-47$.
[14] Luchter B. i in., Funkcjonalność dzielnic samorzadowych w konekście rozwoju miasta na przykładzie wybranej jednostki pomocnidzie Krakowa i Krakowskiego Obszaru Metropolitalnego T Kudtacz red., Wydawnictwo Uniwersytetu Ekonomicznego w Krakowie, Kraków, 2018, s. $165-169$.

przestrzennej miasta Krakowa, PAN, Schneider-Skalska G., Kszztattowanie zdrowego środowiska miesz2004 , s. 10 .
. [16] Schneider-Skalska G., Przestrzenie publiczne w strukturach
mieszkaniowych : element czytelnosci struktury i jakosci izycia, W:

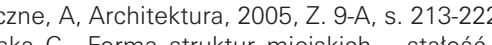
zmienność, rygor czy swoboda?, W: Technical Transactions. Archiecture//Czasopismo Techniczne. Architektura, 2014, Y. 111, iss. 1-A. [18] Szczepańska A.., Krzywnicka l., Lemański L., Urban greenery as
a component of real estate value, W: Real Estate Management and Valuation, 2016, nr 4, $79-87$.

[19] Taczanowski J., Koncepcja zrównowazionego transportu. Przypadek komunikacji tramwajowej $w$ wybranych miastach Europy
Srodkowej i Zachodniej, W: Prace Geograficzne, z. 144, 2016, s. 105 [20] Wptyw klimatu na zdrowie, raport przygotowany przez Koalicje Klimatyczna, HEAL Polska, orpac. A. Muras, 2018, https://loko. press step 09.2019 r.)

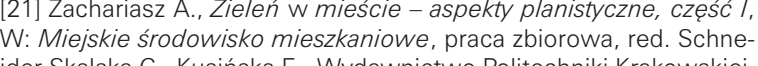
W: Miejkike śŕdowisko mieszkaniowe, praca zbiorowa, red. Schne-
ider-Skalska G. Kusinska E., Wydawnictwo Politechniki Krakowskiej,

\section{ŻRÓDŁA INTERNETOWE:}

(1) Kampus - - oddolna iniciatywa studentów, doktorantów i pra-
cowników Instyututu Geografii i Gospodarki Przestrzennej, https:/l whw facebook com/kampusplusplus ( (dostep Presestrzennej, https:// [2] Global Risk Report opracowywany jest przez Światowe Forum
Ekonomiczne http://reports.weforum. org/global-risks-2018/(dostep

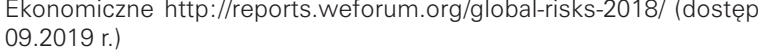
[3] Wydziat Planowania Przestrennego Miasta

Strona informacyina dzielnicy 8 Krakowa, w obrebie które znaiduie Ranking miast powiatowych opracowany ta na podstawe danych GUS, http:///biqdata. wyborcza.pl/ -zobacz-lie-terenow-zielonych.html (dostęp 09.2019 r.) [6] "Kierunki Rozwoju i Zarzadzania Terenami Zielonymi w Krakowie
a lata 2019-2030", dokument przviety Zarzadzeniem Prezydenta

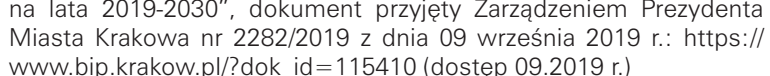

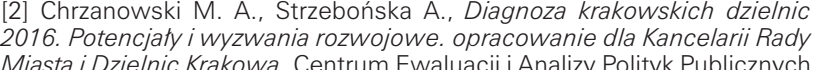
UJ, Kraków 2016, s. 127. Przestrzennej i Komunalnej, Warszawa
HI Dawid W. Dostepność i jakość przestrzeni publicznych w tkance mie

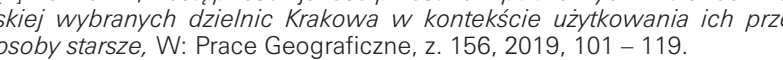

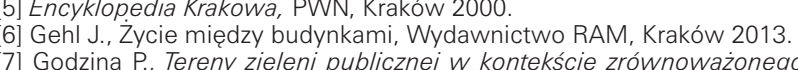
rozwoju miasta, W: Prace Geograficzene, z. 141, 2015,57 - 72.
[8] Guz M., Zielona przestrzen publiczna towicza - zagospodarowanie

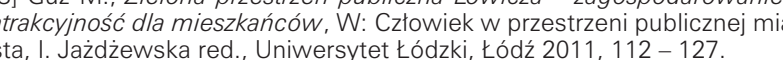
or a realitiz? A selected issues. W. Technical Transactions C Czasopismo

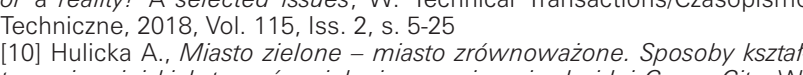
towania mieiskich terenón zieleni iw nawiazaniu do idei Green City, W.

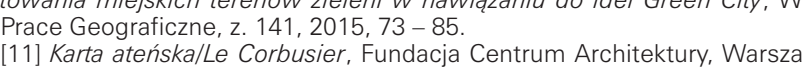

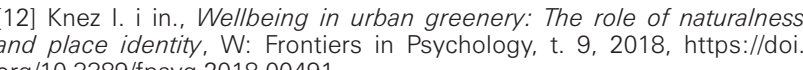

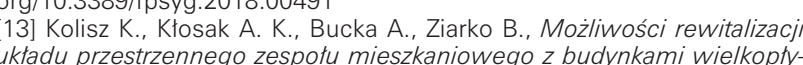
lowymi ina przzktadzie osiedlu , Ruczaj-Zaborze" w Krakowie, W: Przegla 114] Luchter B. i in., Funkcjonalność dzielnic samorzadowych w kontekkowa, W: Funkcionalne miasto w teorii i prak ktyce na pryyktadzie Krakow

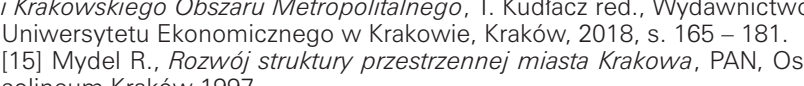
Schneider-Skalska G., Ksztattowanie zdrowego środowiska mieszzaniowe

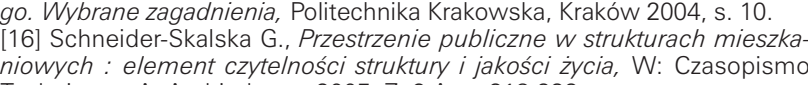

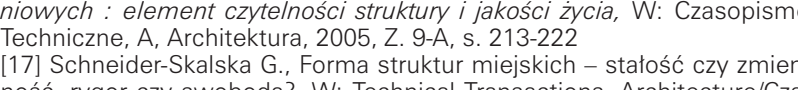
nosc, rygor czy swoboda? W: Technical Transactions. Architecture/Cr
sopismo Techniczne Architektura. 2014. Y 1111 iss 1-A s. 191-208

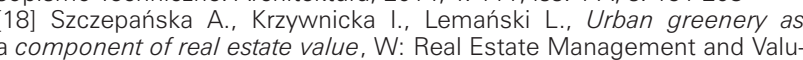
ation, 2016, nr 4, 79 - 87.

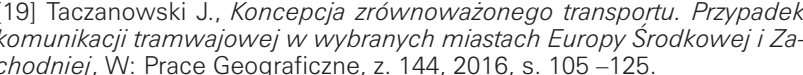

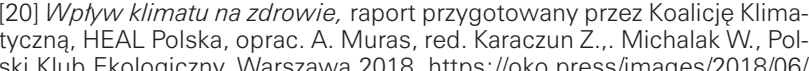

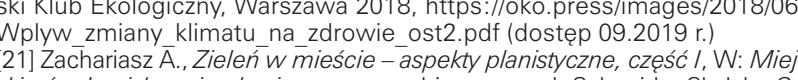

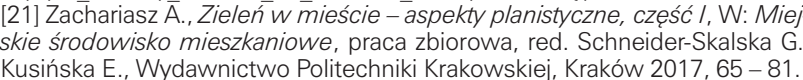

[1] Kampus+- a grassroots initiative by the students, doctoral candidates hittps:///www.tacebook.com/kampusplusplus / /accessed. 09. 2019) rum org/global-irisk-s-2018/ laccessed: 0.2 .20199
[3] Spatial Planning Department of the city of Krakow, https://www.bip. 4] Information website of the eighth district of Krakow, which includes Ruczaj: whw. dzielnicaz.krakow. pi/o-dzielnicy (accessed: 09.2019)

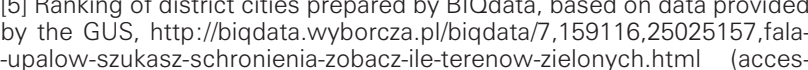

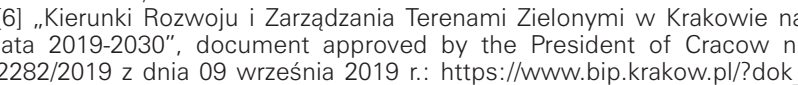
$2282 / 2019$ z dnia 09 września
id $=115410$ (dostęp 09.2019 r.) 